Note

\title{
Determination of seston alkalinity in natural waters*
}

\author{
Victor H. Conzonno \\ Instituto de Limnología 'Dr. Raúl A. Ringuelet'. Facultad de Ciencias Naturales (UNLP). Museo de \\ Ciencias Naturales, Paseo del Bosque s/n, 1900 La Plata, Argentina
}

Received 10 July 1990; accepted 2 January 1991

Key words: natural waters, alkalinity, seston, volumetric titration

\begin{abstract}
Seston alkalinity is a term introduced with the purpose of considering the acid base neutral capacity of the particles integrating it. It can be determined by a simple method, based on a volumetric titration. In alkaline waters, this variable is associated with the insoluble forms of carbonates of the seston.
\end{abstract}

\section{Introduction}

Particulate matter present in natural waters, both inorganic (carbonates, phosphates, borates, silicates, etc.) and organic (humic substances, proteins, etc), are capable of assimilating protons, but, in case of alkaline waters, this consumption is mostly a function of the particulate carbonate content. Formation of insoluble carbonates, among which calcium carbonate in hard waters is the most important, has many implications in limnology because of its influence in the coprecipitation and adsorption of metal ions (Tsusue \& Holland, 1966; Kitano et al., 1971; Okumura \& Kitano, 1986), inorganic nutrients (Jurinak \& Griffin, 1972; Otsuki \& Wetzel, 1972; Murphy et al., 1983), humic substances (Otsuki \& Wetzel, 1973; Stewart \& Wetzel, 1981) and other dissolved organic matter (Suess, 1970; Meyers \& Quinn, 1971). Therefore, carbonates play an important role in the bioavailability and geochemical

\footnotetext{
* Contribution No. 476, Instituto de Limnología, "Dr Raúl A. Ringuelet".
}

cycling of these substances. Evaluation of carbonate precipitation magnitude through stability constants may be rather difficult in a given water body, where the influence of metabolic activity of bacteria, algae and higher plants can not be excluded. Besides, specific determination of carbonate in seston implies the use of methodologies not usually available in laboratories concerned with limnological studies.

The aim of the present work is to report the use of a simple volumetric titration method that computes the acid base neutral capacity of suspended particulate matter; that is to say, seston alkalinity, attributable to a great extent to the insoluble forms of carbonate.

\section{Materials and methods}

The method was applied to water from Chascomús Pond $\left(35^{\circ} 36^{\prime} \mathrm{S}, 58^{\circ} \mathrm{W}\right)$ of the following characteristics: water temperature $22^{\circ} \mathrm{C}$, pH 8.97, total alkalinity $5.78 \mathrm{meq}^{1^{-1}}$, hardness $106.2 \mathrm{mg} \mathrm{CaCO}_{3} \mathrm{l}^{-1}$, specific conductivity $1,600 \mu \mathrm{S} \mathrm{cm}^{-1}$ and seston $133 \mathrm{mg} \mathrm{l}^{-1}$. Samples 
$(100.0 \mathrm{ml})$ were filtered immediately after collection $(1 \mu \mathrm{m}$ pore size glass fiber filter, Micro Filtration Systems, Type GC 50, previously washed with distilled water). The filter was suspended in $50 \mathrm{ml}$ of distilled water and $2.00 \mathrm{ml}$ of sulfuric acid $0.020 \mathrm{~N}$ was added. Once the reaction of acid consuming particles was finished (half an hour was enough), the excess of sulfuric acid was titrated against standard sodium carbonate $0.020 \mathrm{~N}$. The volumetric titration was performed by successive addition of $0.10 \mathrm{ml}$ from a microburette, shaking and taking the $\mathrm{pH}$ until the reading became constant. Parallel titrations were made for the glass fiber filter alone suspended in $50 \mathrm{ml}$ of distilled water, taken as a blank.

\section{Results and discussion}

Figure 1 shows typical titration curves obtained for seston with its own glass fiber filter (a), separately for the glass fiber filter (b) and the sulfuric acid in distilled water (c). Comparison between this and the glass fiber filter curve, indicated a significative consumption of acid by the latter that makes necessary its employment as a

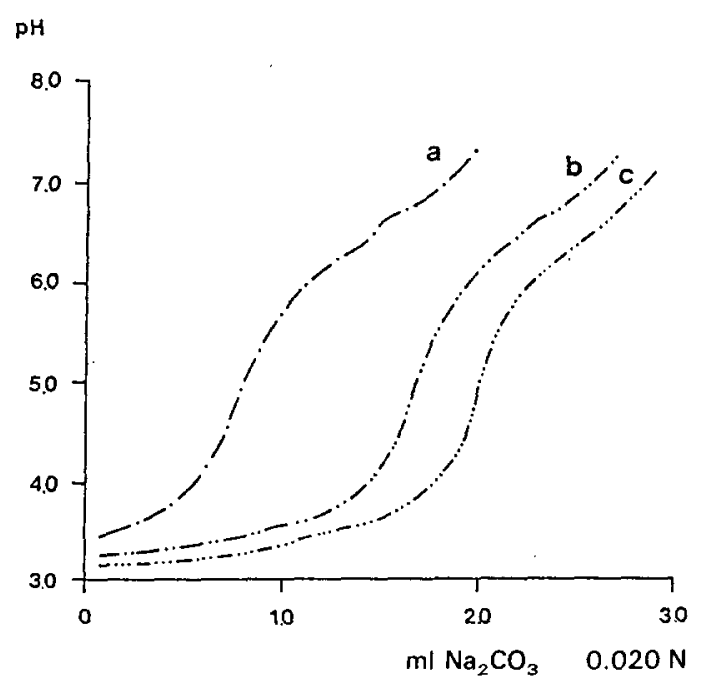

Fig. 1. Titration curve obtained with $\mathrm{Na}_{2} \mathrm{CO}_{3} 0.020 \mathrm{~N}$ over $2.00 \mathrm{ml}$ of $0.020 \mathrm{~N}$ sulfuric acid added to: (a) seston with glass fiber filter suspended in $50 \mathrm{ml}$ of distilled water; (b) glass fiber filter suspended in $50 \mathrm{ml}$ of distilled water and (c) $50 \mathrm{ml}$ of distilled water. blank. Then, calculation of seston alkalinity is performed by considering the difference between the sample inflection point (which includes a glass fiber filter) and the one corresponding to the glass fiber filter alone. After three determinations, a mean value of $0.20 \mathrm{meq} \mathrm{I}^{-1}\left(0.15 \cdot 10^{-2} \mathrm{meq}\right.$ (mg seston $)^{-1}$ ) was obtained with a coefficient of variation of $6 \%$. According to these results, seston alkalinity is about $3.5 \%$ of the total alkalinity. Taking into account the characteristics of this sample, evaluation of the Langelier saturation index (APHA, 1985) gives a value of +1.2 , which indicates that this water is supersaturated with respect to calcium carbonate. Thus, seston alkalinity was mostly due to the insoluble carbonate present in this particular sample.

Alkalinity obtained in this way is a function of particulate matter retained by the filter. So, it is important to note that international standards state that the filters used to separate dissolved from particulate matter should be at the $0.5 \mu \mathrm{m}$ pore size (e.g. Whatman glass fiber $\mathrm{GF} / \mathrm{F}$ ).

\section{Acknowledgements}

I thank Elsa Claverie for her criticism of the manuscript and María de las Nieves Rodriguez and Susana Ilhéro for their technical assistance. This study was supported by the Consejo Nacional de Investigaciones Científicas y Técnicas (CONICET).

\section{References}

APHA, 1985. Standard Methods for the Examination of Water and Wastewater. American Public Health Association, Washington DC, 1268 pp.

Jurinak, J. J. \& R. A. Griffin, 1972. Nitrate ion adsorption by calcium carbonate. Soil Sci. 113: 130-135.

Kitano, Y., N. Kanamori \& T. Oomori, 1971. Measurements of distribution coefficients of strontium and barium between carbonate precipitate and solution. Abnormally high values of distribution coefficients measured at early stages of carbonate formation. Geochim. J. 4: 183-206.

Meyers, P. A. \& J. G. Quinn, 1971. Interaction between fatty acids and calcite in seawater. Limnol. Oceanogr. 16: 992-997. 
Murphy, T. P., K. J. Hall \& I. Yesaki, 1983. Coprecipitation of phosphate with calcite in a naturally eutrophic lake. Limnol. Oceanogr. 28: 58-69.

Okumura, M. \& Y. Kitano, 1986. Coprecipitation of alkali metal ions with calcium carbonate. Geochim. Cosmochim. Acta 50: 49-58.

Otsuki, A. \& R. G. Wetzel, 1972. Coprecipitation of phosphate with carbonates in a marl lake. Limnol. Oceanogr. 17: 763-767.

Otsuki, A. \& R. G. Wetzel, 1973. Interaction of yellow organic acids with calcium carbonate in freshwater. Limnol. Oceanogr. 18: 490-493.
Stewart, A. J. \& R. G. Wetzel, 1981. Dissolved humic materials: Photodegradation, sediment effects, and reactivity with phosphate and calcium carbonate precipitation. Arch. Hydrobiol. 92: 265-286.

Suess, E., 1970. Interaction of organic compounds with calcium carbonate. 1. Geochim. Cosmochim. Acta 34: 157-168.

Tsusue, A. \& H. D. Holland, 1966. The coprecipitation of cations with $\mathrm{CaCO}_{3}$. 3. Geochim. Cosmochim. Acta 30: 439-453. 